\section{AMERICAN ROENTGEN RAY SOCIETY}

Fourtecnth annual meeting, held in Boston, Oet. 1-4, 1918

The President, Dr. Henry K. Panconst, Philadelphia, in the Chair

\section{Officers Elected}

The following officers were elected for the ensuing year: President, Dr, Sidney Lange, Cincinnati; viee-presidents, Dr. D. D. Talley, Riclmmond, Va., und Albert Soiland, Jos Angeles, Cal.; secretary, Dr. W. F. Manges, Philadelphin; treasmer, Dr. Iseonard Reu, Buffalo; executive committec: Dr. Alfred L. Gray, Richmond, Va., chairman; Dr. George C. Jolnston, l'ittslourgh, and Dr. Roland IInmmond, Providence, R. I.

The next annual meeting will be held in Cleveland, Ohio.

\section{Adoption of a Standard Nomenclature for Roentgen Ray Work}

On the recommendation of the Committee on Nomenclature, the society adopted the following terms for use in comnection with all work in which the loontgen ray is the agent employed:

Roentgen: To be pronounced rent-gèn.

Roentgen ray: A ray discovered and deseribed by Wilhelm Konrad Roentgen.

Roentgenology: The study and practice of the Roentgen ray as applied to medicnl science.

Roentgenologist: One skilled in roentgenology.

Roentgenogram: The shadow picture proluced by the

Roentgen ray on a sensitized plate or film.

Roentgenograph (verb): To make a roentgenogram.

Roentgenoscope: An apparatus for examination with the fluorescent sereen excited by the Roentwen ray.

Roentgenoscopy: Examination by means of the roentgenoscope.

Roentrgenography: The ast of making roentgenograms.

Roentgenize: To apply the Roentgen ray.

Roentgenization: Applieation of the Roentgen ray.

Roentgenism: Untoward efiect of the Roentgen ray.

Roentgen diagnosis; Roentgen therapy; Roentgen dermatitis: These terms are self-explanatory.

The secretary was instructed to send a list of these terms and definitions to medical journals, medical publishers and lexicographers.

\section{Journal of the Society}

The Publication Committee announced that hereafter the society would publish a monthly journal, to be known as the American Journal of Roentgenology, to contuin not only original articles, but abstracts of current literature in Knglish and foreign languages dealing with roentgenologric subjects. The editor is Dr. Preston M. Hickey, 32 Adums Avenue, West, Detroit, Michigan.

\section{The Value of Roentgenography in the Prognosis of Bone Lesions}

Dr. Roland Hammond, Providence, R. I.: In bone tuberculosis, improvement is noted in the general condition of the jatient before any change is apparent in the bone. This improvement is shown roentgenographically by the deposit of lime salts in the diseased area and in the adjucent bones. In unfavorable cases the bone undergoes a marked atrophy until its shadow is often hardly to be distinguished from the surrounding soft parts. In these two classes of cases the Roentgen examination confirns the clinical findings. There are other cases, however, in which roentgenograply is an invaluable guide as to the future conduct of the ense. The clinical symptoms may be unfavorable, but roentgenographic examination shows that the bone is not sulliciently healthy to permit of function in the joint. In one of the enses cited the patient's condition was excellest, and the employment of apparatus was about to be omitted. A roentgenogram was inade as a precaution, and showed marked disease with no signs of healing. Soon after this the patient becume worse and died in three months.

\section{The Pituitary in Its Relation to Epilepsy}

D13. G. C. Jolns'Ton, l'ittsburph: 1 exumined the pituitary region in every case of epilepsy obtainable, espereialiy those in which no symptoms of pressure in the region of the pituitary (as evidenced by elanges in the eye-grounds an:l visual ficlds) were present. I was very soon compelled to divide the cases into primnry cerebropathies, pituitary tumors and epilepsy. In the majority of eases, little if any information was obtained by roentgenography of the first class, lut there remained a second class of patients, who with an uneventful history, no injury, the ordinary children's diseases, previous good lenlth, somewhere between the ages of 15 to 35 , began to have attaeks of petit mal, gradualy increasing in severity and frequency.

As our investigations began to include this type of cuses, we noticed decided departures from our conception of the normal in the topography of the sella turciea. These changes were but rarely found in the types of chronic epilepties, but were found with a regularity that gave rise to intense interest in the second class of cases above described, namely, those who with previous good histories, between the ages of 15 and 3.5, beran to develop epilepsy. The changes consisted for the most part in an overgrowth of the anterior and posterior clinoidal processes, which in addition to an increase in area and length are slowly folded over and down on the pituitary gland, enclosing it within a bony hasket. In addition to this process which is evidently one requiring a considerable length of time for its accomplishment, there is very of ten noticeable a decided difference in the size of the pituitary fossa and therefore of the gland itself. 'The fossa is thus largely or completely roofed over in some cases, the anterior and posterior clinoidal processes not only meet but overlap. The frequency with which this condition has been found in this class of pases is quite striking and suggests an etiologie relationship.

(To be continucd)

\section{Current Medical Literature}

AMERICAN
ritles marked with an asterisk (*) are alsstiacted bilow.

\section{Albany Medical Annals}

October, XXXIV, No. 10, pp. $573-636$

1 Rôe of Insects in Trunsmission of Diserse. C. K. Winac, Albany.

2 Some Aspects in Relation to the Chronle Gonorriele, from Standpolnt of Surgery and Eugenles. J. N. Vander Ver'r, Albany.

American Journal of Diseases of Children, Chicago Oetober, $V I$, No. 4, $p p$. $225-288$

3 Cell Content or Milk. D. M. Lewls, New llaven, Conn.

4 *Anatony and physlology of Infant stomacl Based on serial

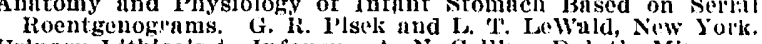
Urinary Iithiasis in Infuncy. $A$. $N$. Collins, Duluth, Minn.

4 "Gastrle secretion of Infauts at Birth. A. He lless, New lork.

4. Anatomy and Physiology of Infant Stomach. -As a result of their investigations the authors conclude that there is no definite normal type of stomach in the infunt. It is holizontal rather than vertical in position when compared with the adult type, and follows certain rather definite forms. They distinguish (1) the ovoid; (2) the tobuce pouch; (3) the pear-shaped stomach with base above and to the left. The shape of the stomach, it is said, does not even depend directly on the amount or eharacter of the food ingested, but rather on the quantity of gas which it contains or acquires. Furthermore, its limits are arenter than we were acenstomed to believe, extending to the liver on the right and at times filling the entire transverse space from one abdominal wall to the other.

Of particular interest from the standpoint of diagnosis is the position of the pylorus. In the mujority of cases this is found comparatively high and behind the pyloric third; at times its position cmnot be determined even though we clenrly see that the food and bismuth has passed out of the visens. 